\title{
Evolving food retail environments in Thailand and implications for the health and nutrition transition
}

\author{
Cathy Banwell ${ }^{1, *}$, Jane Dixon ${ }^{1}$, Sam-Ang Seubsman ${ }^{2}$, S Pangsap ${ }^{2}$, Matthew Kelly ${ }^{1}$ and \\ Adrian Sleigh ${ }^{1}$ \\ ${ }^{1}$ National Centre for Epidemiology and Population Health, Australian National University, Building 62, \\ Canberra, Acton, ACT 0200, Australia: ${ }^{2}$ Sukhothai Thammathirat Open University, Bangkok, Thailand
}

Submitted 21 June 2011: Final revision received 19 July 2012: Accepted 26 July 2012: First published online 10 October 2012

\begin{abstract}
Objective: To investigate evolving food retail systems in Thailand.

Design: Rapid assessment procedures based on qualitative research methods including interviews, focus groups discussions and site visits.

Setting: Seven fresh markets located in the four main regions of Thailand.

Subjects: Managers, food specialists, vendors and shoppers from seven fresh markets who participated in interviews and focus group discussions.

Results: Fresh markets are under economic pressure and are declining in number. They are attempting to resist the competition from supermarkets by improving convenience, food diversity, quality and safety.

Conclusions: Obesity has increased in Thailand at the same time as rapid growth of modern food retail formats has occurred. As fresh markets are overtaken by supermarkets there is a likely loss of fresh, healthy, affordable food for poorer Thais, and a diminution of regional culinary culture, women's jobs and social capital, with implications for the health and nutrition transition in Thailand.
\end{abstract}

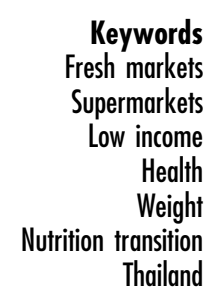

\section{The nutrition and bealth transition}

Thailand is one of several South-East Asian countries in transition from an agrarian to an industrial and postindustrial economy. Thai socio-economic change is increasing and international and local supermarket chains have integrated themselves into food retail at an unprecedented speed ${ }^{(1)}$. A nutrition and health transition is underway with mortality, infectious diseases and undernutrition receding while low birth rates, overweight and obesity emerge $^{(2)}$. Thais are increasingly urbanized and profound changes in their diet include more sugar, oil, fats and animal meat and less vegetables and fruit ${ }^{(2-4)}$. Between 1990 and 2008 the estimated daily energy intake per person in Thailand increased from 9414 to $10627 \mathrm{~kJ}$ (2250 to $2540 \mathrm{kcal})^{(5)}$ and over just two decades (1983-2006) sugar consumption almost tripled from $12 \cdot 7$ to $33 \cdot 2 \mathrm{~kg} /$ person per year ${ }^{(4)}$. Dietary changes, less physical activity due to urbanization, sedentary recreation and occupational changes ${ }^{(6,7)}$ are affecting body size.

Thai obesity has increased. The second (1997) and third (2004) National Health Surveys show that the agestandardized prevalence of adult obesity (BMI $\geq 25 \mathrm{~kg} /$ $\mathrm{m}^{2}$ ) has increased from $25 \cdot 6 \%$ to $30 \cdot 3 \%^{(2)}$. By 2009 obesity affected $40 \cdot 7 \%$ of women and $28 \cdot 4 \%$ of men $^{(3)}$. Population weight gain is more pronounced in urban areas and in the more economically developed Bangkok and the Central region, and lowest in the poorer North and North Eastern regions ${ }^{(3,4)}$. CVD, non-insulin dependent diabetes mellitus, hormone-related cancers and gallbladder disease are all expected to surge ${ }^{(5)}$. Considerable economic and social costs associated with obesity are anticipated, with implications for the healthcare system $^{(6)}$. For example, in China and India the costs of obesity and related diseases will outstrip the costs of undernutrition in the next 25 years $^{(7)}$.

\section{The evolving food retail landscape}

Thailand now stands out among other South-East Asian nations for its rapid growth in modern food retail outlets ${ }^{(8,9)}$. Traditionally, at fresh markets or night markets stallholders sold meat, fish, fresh vegetables, fruits and herbs ${ }^{(10,11)}$, and dry goods were bought from locally owned stores. Supermarkets, large self-service retail stores, first appeared in Bangkok in the 1960s ${ }^{(12)}$ and were followed there by an explosion in modern retail formats associated with a booming economy ${ }^{(13)}$. Later in 1989, 7-Eleven convenience stores arrived, located near commuter stops ${ }^{(14)}$.

With the 1997 financial crisis, partnerships between Thai and foreign firms were dissolved and the foreign partners took control. These transnational food companies proceeded to expand their operations; for example, from eighteen hypermarkets (defined as supermarkets with floor size of $\left.15000-20000 \mathrm{~m}^{2}\right)^{(13)}$ in 1996, to 148 a decade later. 
Their diffusion into regional centres occurred as rural incomes rose and rural people became more accustomed to urban-style living. The main companies were Tesco (UK), Carrefour (French) and Big C (French) ${ }^{(15)}$, although Thailand's own CP (Chaoren Pokphand) group owns the 7-Eleven chain ${ }^{(13)}$ (the market leader in this category) ${ }^{(16)}$ and the Siam Makkro chain. The rapid expansion of supermarkets and hypermarkets ${ }^{(14,15)}$, and the annual loss of about 25000 small retailers ${ }^{(17)}$, have closely paralleled Thailand's urbanization and industrialization.

Thailand's food retail system now consists of a traditional sector (fresh markets and 'mom and pop' stores) that caters to the 'price sensitive' and 'traditional diet' consumers ${ }^{(18)}$ and a modern sector (hypermarkets, supermarkets and convenience stores) which has dominated the expansionary process since $2000^{(19)}$. The modern retail sector has increased from about $35 \%$ of market share in 1999 to $48 \%$ in $2005^{(20)}$. In 1996, supermarkets, hypermarkets and convenience stores had $10.5 \%$ of the retail food sales and by 2000 their share had increased to $18 \cdot 4 \%{ }^{(13)}$. New legislation and regulations introduced in the 2000s have slowed the growth of foreign-owned supermarkets somewhat ${ }^{(9)}$. Nevertheless, super/hypermarkets are rapidly gaining ground with their number increasing from 110 in 1997 to 391 in 2007, alongside a sixfold growth in convenience stores ${ }^{(9)}$. This modern food retail growth has corresponded with a national decline in the number of fresh markets, falling from 160 to fifty in the past decade in Bangkok alone ${ }^{(21)}$.

The growth of super/hypermarkets may have a role in the Thai nutrition transition through two mechanisms. First, it has implications for food affordability, particularly for the poorer $55 \%$ of the population. In 2004, the average market basket of goods from a traditional market cost $9 \%$ less than the equivalent basket of goods from the three major hypermarket retailers ${ }^{(13)}$. Recently, in Chiang Mai, it was observed that fresh produce at supermarkets cost between two and four times more than at fresh markets $^{(22)}$. Internationally, it is the wealthier, younger, urban middle class who tends to shop at supermarkets ${ }^{(23-25)}$.

Second, supermarket expansion could influence food choice, weight and health. Hawkes ${ }^{(17)}$ argues that supermarkets can be both positive by making 'a more diverse diet available and accessible to more people and negative - supermarkets can reduce the ability of marginalized populations to purchase a high-quality diet, and encourage the consumption of energy-dense, nutrient-poor, highly-processed foods' (p. 657). They have an impact on the nutrition transition because overall 'consumers eat more, whatever the food' ${ }^{(17)}$. Currently, both healthy and unhealthy foods are available at supermarkets, fresh markets and other venues for urban Thais. However, small fresh produce providers may disappear as supermarkets drive out competitors and gain market share over time, leaving supermarkets to provide an abundance of cheaper processed foods and more expensive fresh foods.

Drawing on consumer and retailer views we discuss how Thai fresh markets are responding to the growth of supermarkets and what the potential outcomes of their expansion may be. Evidence suggests that the dynamics of the nutrition transition may be influenced, and the health and well-being of poorer Thais may be disproportionally affected.

\section{Study methods}

Fieldwork was undertaken progressively between 2006 and 2011 in seven fresh markets located in each of the North, North Eastern, Central and Southern regions (see Table 1 and Fig. 1), which represent major cultural, geographical, culinary and socio-cultural variation in Thailand. Central Thailand is the wealthiest area and the North Eastern or Isan area is the poorest ${ }^{(11)}$. The fresh markets were located in major regional centres (including the outskirts of Bangkok) and were selected to represent a variety of fresh market types, ranging from mainly retail to wholesale, renovated or not, and car or pedestrian focused.

The research team of eight people included bilingual Thai and Australian research assistants, a Thai nutrition epidemiologist, an Australian food sociologist and a medical anthropologist. The Thai assistants worked with local people in each city to set up the interviews and

Table 1 Fieldwork sites

\begin{tabular}{|c|c|c|c|}
\hline Region & Major city & Markets & Regional culinary characteristics \\
\hline Central & Bangkok & $\begin{array}{l}\text { Nonthaburi Provincial Market } \\
\text { on Bangkok periphery } \\
\text { Sam Chuck Market, } 90 \mathrm{~km} \\
\text { from Bangkok }\end{array}$ & $\begin{array}{l}\text { Dishes are influenced by Indian food (i.e. use of coconut } \\
\text { milk in curries) and by the royal cuisine }\end{array}$ \\
\hline Northern & Chiang Mai & Central Tanin Market & $\begin{array}{l}\text { People use sticky rice, more herbs and less chilli. Dishes } \\
\text { are influenced by minority group and neighbouring } \\
\text { countries' culinary cultures }\end{array}$ \\
\hline North Eastern & Khon Kaen & Bang Lam Poo Market & $\begin{array}{l}\text { This is a drier, less fertile area where Isan food, including } \\
\text { sticky rice, hot chillies, fermented fish and insects, is } \\
\text { popular }\end{array}$ \\
\hline Southern & Nakhon Sri Thammarat & $\begin{array}{l}\text { Kukwang Municipal Market } \\
\text { Mae Som Jit Market }\end{array}$ & $\begin{array}{l}\text { In this region, seafood and hot spices, white } \\
\text { non-glutinous rice and fresh vegetables are popular }{ }^{(11)}\end{array}$ \\
\hline
\end{tabular}




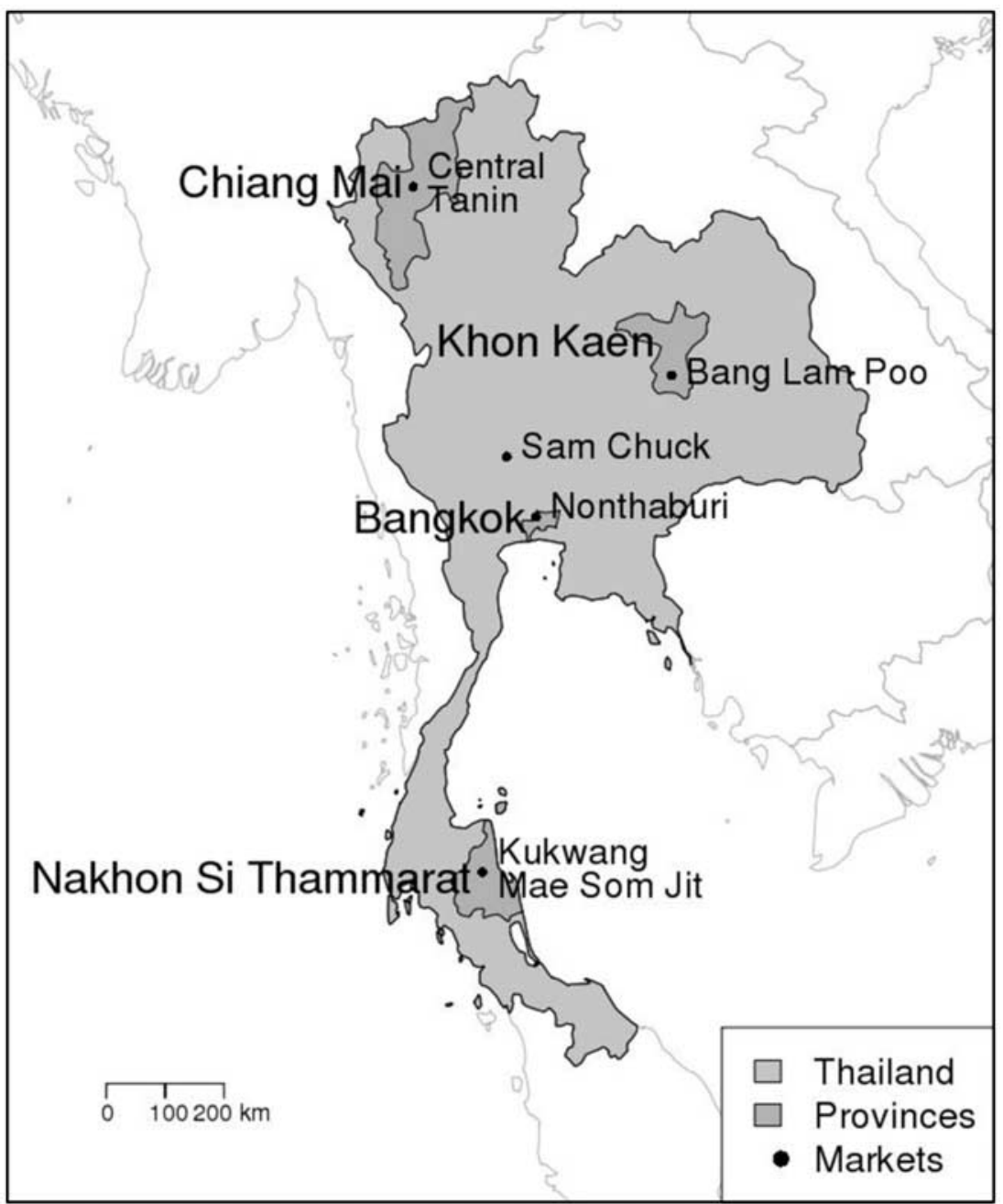

Fig. 1 Map of Thailand showing fieldwork sites

focus groups and were present at the markets. Each market was visited over a period extending from 1 to $4 \mathrm{~d}$ but not every team member was present at each market visit.

Rapid assessment procedures ${ }^{(26)}$, consisting of a range of ethnographic research methods adapted for short-term fieldwork including the following, were used (Table 2).

Interviews were either (i) audio-recorded in Thai and later translated into English or (ii) Thai researchers provided translations while interviews were occurring which were then spoken into audio-recorders. Participants in focus groups and formal interviews were provided with food and drink. During opportunistic interviews (where prior arrangements had not been made for an interview), English-speaking and Thai researchers jointly interviewed participants and recorded responses in notebooks. The team met at the end of the day to discuss observations, photographs, findings and interpretations. Data were examined for common patterns of responses which were then integrated with researchers' field notes of observations to identify major themes.

\section{Results}

\section{Fresh markets under threat}

Two markets in the Central region typify the impact of Thai economic and social trends on fresh markets. They illustrate how local communities and fresh market vendors cannot ignore the economic and cultural consequences of supermarket development.

Nonthaburi, $32 \mathrm{~km}$ from Bangkok, has always been farming land and its culture is rooted in home production with a well-established reputation for some of the best tropical fruit in the country. Now, construction sites are being built here as migrants working in Bangkok look for housing. Most farmers have sold their land, local orchards have disappeared, and vegetables and fruits from other provinces have replaced local products in the fresh market.

The Nonthaburi market was rundown and dirty and the Nonthaburi Municipal Office was keen to renovate it; however, renovating fresh markets causes considerable disruption to stallholders who lose their income while improvements are made. Stallholders fear that renovations 
Table 2 Fieldwork methods

\begin{tabular}{|c|c|c|}
\hline Method & Description & Number \\
\hline Key informant interviews & $\begin{array}{l}\text { Market managers, public health officials, Thai food experts (e.g. professional cook, food writer, } \\
\text { academics), monk, school teacher, women who are interested in Thai cooking }\end{array}$ & 13 \\
\hline Focus groups & $\begin{array}{l}\text { Market vendors from a range of stalls (e.g. fruit and vegetable, pastries, dry goods, fresh meat, } \\
\text { spices and fermented goods) } \\
\text { Elderly women attending a monastery }\end{array}$ & 5 \\
\hline Brief questionnaire & $\begin{array}{l}\text { Face-to-face questionnaire with stallholders at all markets about customer preferences, produce, } \\
\text { changes over time, difficulties in being a stallholder and social interactions }\end{array}$ & 110 \\
\hline Consumer interviews & $\begin{array}{l}\text { Consumers from two markets to explore their perceptions of food availability changes and social } \\
\text { interactions }\end{array}$ & 27 \\
\hline Vendor interviews & Vendors from all markets & 15 \\
\hline Photographs & A photographic record was made at every market to cover the types of stalls and range of produce & 100s \\
\hline
\end{tabular}

are an excuse to reclaim the fresh market site and sell it for more lucrative uses. However, without renovations, including access to car parking and a cleaner appearance, such markets have trouble competing with adjacent supermarkets and minimarts. Half of the respondents to the survey of consumers at this fresh market (in the wealthier Central region) also shopped at the large modern supermarkets. This mixed mode of shopping contrasted with fresh markets in other regions where there was less patronage of modern retail outlets.

Sam Chuck fresh market in Suphanburi provides a contrasting history and appearance. For centuries Suphanburi has been a river market town, and has always sold a wide array of produce. In 2003, the 100-year-old wooden market was completely refurbished with a view to becoming a cultural institution and a tourist destination. During the week the major consumers at the market are local residents, while at weekends, tourists arrive in large numbers courtesy of bus tours. The value of the traditional character of the Sam Chuck market is being vigorously protected by stallholders who are threatened by the arrival of a new Tesco Lotus nearby. As in other localities $^{(22)}$ they have held public demonstrations against Tesco Lotus and the market site is festooned with a banner objecting to it. Emphasizing the threat to the community rather than the individual, a male vendor said:

I don't mind Lotus coming here: it's air conditioned, fair price and good quality, but I don't want it to come too close. If it's far and does not affect the community's economy, I'm okay, but otherwise it could be a threat.

Thai fresh market vendors, with support from their customers, are attempting to resist and compete with major supermarket retailers by drawing on claims of convenience, quality, value and tradition. At the same time, supermarkets are adopting some attributes of fresh markets in their attempts to gain market share ${ }^{(27)}$.

\section{Competing with supermarkets - what fresh markets do well}

The material below encapsulates the key dynamics present across the seven fresh markets as market vendors attempt to compete with modern retailing in the following areas.

\section{A Thai style of 'convenience'}

Fresh market vendors sold pre-cooked and packaged foods, including cooked vegetables, fried goods and bowls of curries, stir fries and local regional dishes. Curry pastes and powders are sold in single meal portions as well as in larger quantities, and some stalls also sold one meal sized plastic bags of fresh vegetables designed for soups. Fish are partially prepared by being de-headed and gutted. Small portions of sweets and desserts were also readily available. 'Plastic bag housewives'(28) frequently purchased the evening meal in a plastic bag on their way home from work. Vendors sold their produce in flexible amounts, ranging from a $10 \mathrm{~kg}$ sack of rice or large tins of oil to a single carrot, thus catering to individuals and families who may only have enough money to buy provisions for one or two meals at a time ${ }^{(13)}$ or who have little storage capacity. Many fresh market shoppers typically shopped daily in small quantities, thereby assuring that their food is fresh, easily transportable and affordable. Stallholders agreed that they charge more now per amount than in the past but sell in smaller quantities.

\section{Food safety}

Due to the common perception that fresh markets are less hygienic than supermarkets some markets have upgraded their infrastructure, while others are contemplating changes. Local officials monitor standards of hygiene, determining how food can be displayed and issuing instructions to vendors on cleanliness, food handling and storage. For example, at Chiang Mai's Tanin fresh market the public health department visited stallholders every couple of months. Stallholders are taught to wash and soak vegetables for 15 min with a tablespoon of baking powder dissolved in water to clean them and remove pests, before rinsing thoroughly. Surveyed retailers rated food safety, including anxiety about the use of pesticides and other chemicals, as the most important influence on consumers' food choice. Over the preceding decade considerable improvements have been made to fresh 
markets to reduce food-borne disease risks ${ }^{(29)}$, with one consumer observing that now 'sellers are more sanitary in their methods'. Despite these improvements, supermarkets use food safety to claim superiority and create a point of distinction ${ }^{(30)}$, particularly for aspiring middleclass Thais ${ }^{(22)}$. They advertise use of the Hazard Analysis and Critical Control Points system; and their Western appearance, bright lights and polished floors reinforce perceptions that their produce is safe, modern and convenient. However, in the modern-looking, brightly lit and orderly Tanin fresh market, stalls were advertising produce that was certified as organic, a trend that is borrowed from the supermarkets. In other fresh markets many stalls displayed signs saying that they followed food safety standards and occasionally they displayed government certification (usually the Ministry of Agriculture's Good Agricultural Practices) which can inflate the price of a food considerably in both retail formats ${ }^{(20)}$.

\section{Improved freshness and appearance}

At the Chiang Mai Gate fresh market, one focus group stallholder said 'if the vegetables don't look good, customers don't eat'. Thus, stallholders attempted to provide good-looking fresh produce. However, some vendors argued that the demand for produce that was blemishfree has led to the overuse of pesticides and the use of food colourings and additives. In this regard, many vendors and consumers thought that food may look better but not taste as good as in the past.

\section{Protecting regional culinary culture}

Fresh markets sell regional products. Sticky rice, which is regarded as 'heartful' (filling) in the north, is available in Chiang Mai markets; while in the south, hot and spicy curries are sold. Vendors and purchasers frequently expressed a preference for their regional foods while buyers often sought specific local vegetables ${ }^{(31)}$. Stallholders also noted that markets were increasingly attracting Thai and international tourists who were looking for authentic Thai foods including regional products. Markets also play an important part in the ritual and symbolic routines of regional Thai life ${ }^{(31)}$. When we visited the southern regional city of Nakhorn Sri Thamarat, the activities associated with an important festival at a nearby Buddhist shrine (the 10th month merit-making festival) were supported by the sale of festival foods in the market. Pramahathat, pagoda-shaped decorated food offerings, sat alongside various types of Kanom or pastries that stay fresh longer than other foods. These are offered to monks at the second of the three-month Buddhist period of restraint because the monks rely on foods that store well.

Fresh markets compete with supermarkets as local tourist attractions ${ }^{(22,32)}$ with the latter clearly recognizing the importance of the cultural dimension by selling regional produce and participating in local festivals. Thai families visit supermarkets on weekends often after payday. Children are given rides or treats while parents buy bulk quantities of mainly dry goods, laundry items, toiletries and clothes.

\section{Implications of supermarket dominance for the Thai nutrition transition, bealth and well-being}

Research elsewhere ${ }^{(33)}$ shows that 'as supermarkets "take over" food retailing they become drivers of the overall food system' (p. 415). This shift in power has implications for health and for local food environments.

Thais become increasingly exposed to obesogenic foods Super/hypermarkets have proliferated in Thailand, increasing the availability, accessibility and affordability of energydense foods ${ }^{(34)}$, because they sell processed foods more cheaply than traditional retailers although fresh foods were more expensive ${ }^{(35)}$. Supermarket shoppers are inclined to value foods such as Western-style bakery products $^{(27)}$ whereas fresh market-based respondents rarely ate Western foods.

\section{A potential loss of accessible, plant-based, dietary diversity that is healthy and priced for poorer segments of the population}

Fresh markets have traditionally sold locally harvested Thai plants in small quantities at affordable prices ${ }^{(29)}$ with credit given to regular shoppers. Recently, an even greater profusion of imported, nationally and locally produced fruit and vegetables has become available in fresh markets ${ }^{(29)}$. Local Thai vegetables and greens are displayed next to carrots from Australia and apples from China. A wider range of red and white meat now complements the traditional protein source of fish. Other traditional fresh produce and wild protein sources (lizards, insects, frogs) are now farmed and sold in fresh markets but are rarely sold in super/hypermarkets.

\section{Loss of social capital connected to fresh markets}

All sampled fresh markets illustrated the complex ways that fresh markets are integrated into daily rituals and in the process anchor a way of life for many consumers and for vendors. Reflecting on the attributes of the market in comparison to supermarkets, informants commented: 'This is a way of life: always been like this'; 'It's a great atmosphere'; 'It brings great relations between producers and consumers'; 'We bring a brother-sister relationship between buyers and sellers ... it's still present, but not as much as the past'; and 'People of my age, love the relationship with the sellers'. Consumers become interconnected with market vendors by making daily visits on their way home from work or other activities. As a result, they consolidated relationships with their preferred traders and established social networks based on familiarity and mutual benefit, which is similar to what Kirwan ${ }^{(36)}$ described as 'regard'. 
A loss of livelihood particularly for women market retailers Most fresh market stallholders, and roughly half the wholesalers, are women ${ }^{(37)}$. They are often closely connected by intertwined kinship, friendship and commercial networks. Stalls were passed down through generations (often from mother to daughter), stallholders bought from and sold to each other, and consumers became part of these networks over many years. Market women's close relationships evolve into support roles which may include: financial sharing and support programmes, sickness benefit support, counselling services, assisting abused women and sharing market information ${ }^{(37)}$. Thus women are particularly vulnerable to changes in retail food environments.

\section{Undermining highly valued regional culinary cultures}

Respondents proposed that fresh markets were the commercial repository of local and regional produce and dishes. In our surveys, safety, health and price were the first consideration in food preferences. 'Culture', meaning regional ingredients and dishes, rated second. Sellers and consumers conceded that recently there was some blurring of the boundaries with other regions and Western dishes being sold.

\section{Discussion and conclusion}

There are many features of fresh markets that super/ hypermarkets cannot replicate. Thais shop and eat at fresh markets, often buying small amounts of mainly fresh foods daily at affordable prices and building health protection through the social capital that follows from strong social ties ${ }^{(38)}$. The markets supply tens of thousands of often independent livelihoods, particularly to women ${ }^{(37)}$. In contrast, supermarkets do not establish a strong relationship between staff and consumers and they rely less on local produce. They are less adaptable as evidenced by the 2011 Thai floods when they ran out of stock quickly while fresh markets continued to operate. Nor are they as attractive for local or international tourists looking for an authentic culinary experience.

A limitation of the present study is that we have not yet directly investigated Thai health outcomes associated with supermarket growth. The current ready access to fresh markets appears to favour poorer Thais, who have lower BMI than wealthier and more urban Thais ${ }^{(39,40)}$, and the increase in hyper/supermarkets in Thailand is matched by the rapid growth of obesity ${ }^{(1)}$. Longitudinal data from our 2005 cohort $^{(41)}$ along with ethnography of food retail environments and food consumption will be used to examine these relationships more closely.

It is uncertain whether fresh markets will continue to dominate the sale of fresh vegetables in $\mathrm{Asia}^{(30,33,42)}$ in the future. Globally, super/hypermarket chains have been successful at gaining market share over time with mixed public health and economic gains and losses. High-fat, sugary and salty foods become more accessible and affordable ${ }^{(17)}$, and may usurp the place of raw staple foods in individual diets ${ }^{(35)}$. However, results depend on the existing food retail environmental and cultural context of supermarket growth ${ }^{(9,43)}$. In Guatemala frequent supermarket shopping is associated with increased purchases of processed foods associated with increased $\mathrm{BMI}^{(44)}$, whereas diet quality improved slightly for the well-off in Tunis who used supermarkets ${ }^{(45)}$. Supermarkets stock large volumes of processed foods and narrow the range of nearby competing food retailers which may sell cheaper, fresh food ${ }^{(43)}$. A source of fresh, affordable food for poorer Thais may disappear along with fresh markets' contributions to Thai culinary culture and to an esteemed and socially valued way of life (social capital) that contributes to positive social health status ${ }^{(38)}$. Poorer market vendors may suffer financial risk and eventually close as markets attempt to compete with supermarket claims of greater cleanliness, hygiene, food safety and the appeal of modernity itself. Eventually, if fresh markets disappear, Thai supermarkets may follow the Western pattern where they supply healthier diets to the educated and wealthy who can afford them, and cheaper, highly processed foods to the poor, thus increasing health inequalities.

National and particularly foreign-owned supermarket growth has been contentious in Thailand. Responding to their growth in more vulnerable regional centres, Mutebi ${ }^{(8)}$ argues for greater policy intervention in addition to recent government regulations imposed on hyper/supermarkets limiting growth, location and trading hours. There should also be positive protection for fresh markets with financial assistance for infrastructural upgrades, cheap credit to stallholders $^{(25)}$, and more government promotion of fresh markets as safe, healthy food retail outlets.

Ultimately, the decrease in fresh markets would put food security (dietary needs and food preferences) ${ }^{(46)}$ at risk, particularly for poorer Thais. Other Asian countries, which are also anticipating rapid increases in obesity and weight-related diseases, will be monitoring Thai policy responses and health outcomes closely.

\section{Acknowledgements}

Source of funding: This study was supported by the International Collaborative Research Grants Scheme with joint grants from the Wellcome Trust UK (GR071587MA) and the Australian National Health and Medical Research Council (NHMRC; 268055), and a global health grant from the NHMRC (585426). Conflicts of interest: There is no conflict of interest for any author. Authors' contribution: All authors were involved in fieldwork. C.B. and J.D. took the lead in writing the paper and other authors contributed to revisions. Acknowledgements: The authors thank Ivan Hannigan for the map; the staff at Sukhothai 
Thammathirat Open University (STOU) who assisted with student contact and the STOU students who are participating in the 2005 cohort study; and Dr Bandit Thinkamrop and his team from Khon Kaen University for guiding them through the complex data process. Ethics clearance for the Thai health-transition study was obtained from STOU.

\section{References}

1. Kelly M, Sleigh A, Banwell C et al. (2010) Nutrition transition, food retailing and health equity in Thailand. Australasian Epidemiologist 13, 4-7.

2. Aekplakorn W, Hogan $\mathrm{M}$, Chongsuvivatwong $\mathrm{V}$ et al. (2007) Trends in obesity and associations with education and urban or rural residence in Thailand. Obesity (Silver Spring) 15, 3113-3121.

3. Aekplakorn W (2011) Report on the Thai National Health Examination Survey 2008-09. Nonthaburi: National Health Examination Survey Office.

4. Ministry of Public Health (2008) Thailand Health Profile 2005-2007 (chapter 4). http://www.moph.go.th/ops/health_ 50/4_8_ENG.pdf (accessed September 2012).

5. Food and Agriculture Organization of the United Nations (not dated) Energy consumption for countries. http:// www.fao.org/fileadmin/templates/ess/documents/food_ security_statistics/FoodConsumptionNutrients_en.xls (accessed September 2012).

6. World Health Organization (2000) Nutrition in Southeast Asia. New Delhi: WHO Regional Office for Southeast Asia.

7. Popkin B (2003) The nutrition transition in the developing world. Dev Policy Rev 21, 581-597.

8. Mutebi A (2007) Regulatory responses to large-format transnational retail in south-east Asia. Urban Stud $\mathbf{4 4}$, 357-379.

9. Shannon R (2009) The transformation of food retailing in Thailand 1997-2007. Asia Pac Bus Rev 15, 79-92.

10. Lefferts L (2005) Sticky rice, fermented fish, and the course of a kingdom: the politics of food in northeast Thailand. Asian Stud Rev 29, 247-258.

11. Seubsman S-A, Suttinan P, Dixon J et al. (2009) Thai meals. In Meals in Science and Practice, pp. 413-451 [H Meiselman, editor]. Cambridge: Woodhead Publishing.

12. Wigglesworth EF \& Brotan J (1996) Retailing trends in Thailand. $J$ Retail Summer issue, 41-51.

13. Schaffner D, Bokal B, Fink S et al. (2005) Food retail-price comparison in Thailand. J Food Distribut Res 36, 167-171.

14. Tokrisna R (2007) Thailand's changing retail food sector: consequences for consumers, producers, and trade. http:// www.pecc.org/resources/doc_view/394-thailand-changingretail-food-sector-consequences-for-consumers-producersand-trade (accessed September 2012).

15. Kanchoochat V (2008) Services, servility and survival: the accommodation of big retail, in Thailand after the 1997 crisis. In Thai Capital After the 1997 Crisis, pp. 85-104 [P Phongpaichit and C Baker, editors]. Singapore: ISEAS Publishers.

16. US Department of Agriculture (2000) Thailand Retail Food Sector 2000. GAIN Report \#TH0116. Washington, DC: USDA, Foreign Agricultural Service.

17. Hawkes C (2008) Dietary implications of supermarket development: a global perspective. Dev Policy Rev 26, 657-692.

18. US Department of Agriculture (2004) Thailand Exporter Guide Annual 2004. GAIN Report \#TH4123. Washington, DC: USDA, Foreign Agricultural Service.

19. Kuipers P (2007) Thailand after the coup: struggle between modern and traditional. Elsevier Food International 10, issue 1 (February).
20. Vandergeest P (2006) Natural Markets: remaking food and agriculture in Southeast Asia. Presented at 2006 Annual Meeting of the Association of American Geographers, Chicago, Illinois, 7-11 March 2006.

21. Sriangura V, Sakseree A (2009) Tradition strikes back. Bangkok Post, 1 May 2009.

22. Isaacs B (2009) Imagining Thailand in European hypermarkets: new class-based consumption in Chiang Mai's 'cruise ships'. Asia Pac J Anthropol 10, 348-363.

23. Gorton M, Sauer J, Supatpongkul P (2009) Investigating Thai shopping behavior: wet-markets, supermarkets and the 'big middle'. Presented at International Association of Agricultural Economists Conference, Beijing, China, 16-22 August 2009.

24. D'Haese M, Van den Berg M \& Speelman S (2008) A country-wide study of consumer choice for an emerging supermarket sector: a case study of Nicaragua. Dev Policy Rev 26, 603-615.

25. Figuié M \& Moustier P (2009) Market appeal in an emerging economy: supermarkets and poor consumers in Vietnam. Food Policy 34, 210-217.

26. Manderson L \& Aaby P (1992) An epidemic in the field? Rapid assessment procedures and health research. Soc Sci Med 35, 839-850.

27. Isaacs B, Dixon J \& Banwell C (2010) Fresh market to supermarket: nutrition transition insights from Chiang Mai, Thailand. Public Health Nutr 13, 893-897.

28. Yasmeen G (1996) 'Plastic-bag housewives' and postmodern restaurants? Public and private in Bangkok's foodscape. Urban Geogr 17, 526-544.

29. Dixon J, Banwell C, Seubsman S-A et al. (2007) Dietary diversity in Khon Kaen, 1988-2006. Int J Epidemiol 36, 518-521.

30. Goldman A, Krider R \& Ramaswami S (1999) The persistent competitive advantage of trandtional food retailers Asia: wet markets' continued dominance in Hong Kong. J Macromark 19, 126-139.

31. Bunyannupap Y (2000) Consumer knowledge on local vegetable consumption in the markets of Chiang Mai Municipal Area. J Natl Res Council Thailand 32, 27-52.

32. Euromonitor International (2008) Retailing - Thailand. London: Euormonitor International Ltd.

33. Reardon T, Henson S \& Berdegue J (2007) Proactive fasttracking diffusion of supermarkets in developing countries: implications for market institutions and trade. J Econ Geogr 7, 399-431.

34. Hawkes C (2006) Uneven dietary development: linking the policies and processes of globalization with the nutrition transition, obesity and diet-related chronic diseases. Global Health 2, 4 .

35. Vinkeles MNV, Gomez M \& Colagiuri R (2009) Do socioeconomic factors influence supermarket content and shoppers' purchases? Health Promot J Aust 20, 241-246.

36. Kirwan J (2006) The interpersonal world of direct marketing: examining conventions of quality at UK farmers' markets. J Rural Stud 22, 301-312.

37. Jaibun K (2006) Markets and lifestyles: a preliminary survey of literature concerning markets and Thai society. In Markets in Life and Life in Markets, pp. 19-102 [S Chaisingkanaon, editor]. Bangkok: Sirinthon Humanities Research Centre.

38. Kawachi I, Kennedy B, Lochner K et al. (1997) Social capital, income inequality, and mortality. Am J Public Health 87, 1491-1498.

39. Banwell C, Lim L, Seubsman S-A et al. (2009) Body mass index and health-related behaviours in a national cohort of 87,134 Thai open university students. J Epidemiol Community Health 63, 366-372.

40. Lim L, Kjellstrom T, Sleigh A et al. (2009) Associations between urbanisation and components of the health-risk 
transition in Thailand. A descriptive study of 87,000 Thai adults. Global Health Action 2, 10.3402/gha.v2i0.1914.

41. Sleigh A, Seubsman S-A, Bain C et al. (2008) Cohort profile: The Thai Cohort of 87,134 Open University students. Int J Epidemiol 37, 266-272.

42. Gorton M, Sauer J, Supatpongkul P (2009) Investigating Thai shopping behaviour: wet-markets, supermarkets and food quality. Presented at 83rd Annual Conference of the Agricultural Economics Society, Dublin, Ireland, 30 March-1 April 2009.
43. White M (2007) Food access and obesity. Obes Rev 8, 99-107.

44. Asfaw A (2008) Does supermarket purchase affect the dietary practices of households? Some empirical evidence from Guatamala. Dev Policy Rev 26, 227-243.

45. Tessier S, Traissac P, Maire B et al. (2008) Regular users of supermarkets in Greater Tunis have a slight improved diet quality. J Nutr 138, 768-774.

46. World Health Organization (1996) Food Security. http://www.who.int/trade/glossary/story028/en/ (accessed September 2012). 